\title{
Enhancing Electricity Generation Using a Laccase-Based Microbial Fuel Cell with Yeast Galactomyces reessii on the Cathodes ${ }^{\mathrm{S}}$
}

\author{
Pimprapa Chaijak ${ }^{1}$, Chontisa Sukkasem ${ }^{2}$, Monthon Lertworapreecha ${ }^{3}$, Piyarat Boonsawang ${ }^{4}$, Sutthida Wijasika ${ }^{5}$, \\ and Chikashi Sato ${ }^{6 *}$ \\ ${ }^{1}$ Department of Biotechnology, Faculty of Science, Thaksin University, Phatthalung Campus, Phatthalung 93210, Thailand \\ ${ }^{2}$ Department of Food Science and Technology, Faculty of Technology and Community Development, Thaksin University, Phatthalung \\ Campus, Phatthalung 93210, Thailand \\ ${ }^{3}$ Department of Biology, Faculty of Science, Thaksin University, Phatthalung Campus, Phatthalung 93210, Thailand \\ ${ }^{4}$ Department of Industrial Biotechnology, Faculty of Agro-Industry, Prince of Songkla University, Hatyai Campus, Hatyai, Songkla 90112, Thailand \\ ${ }^{5}$ Department of Biotechnology, Faculty of Technology and Community Development, Thaksin University, Phatthalung Campus, Phatthalung \\ 93210, Thailand \\ ${ }^{6}$ Department of Civil and Environmental Engineering, College of Science and Engineering, Idaho State University, Pocatello, ID 83209, USA
}

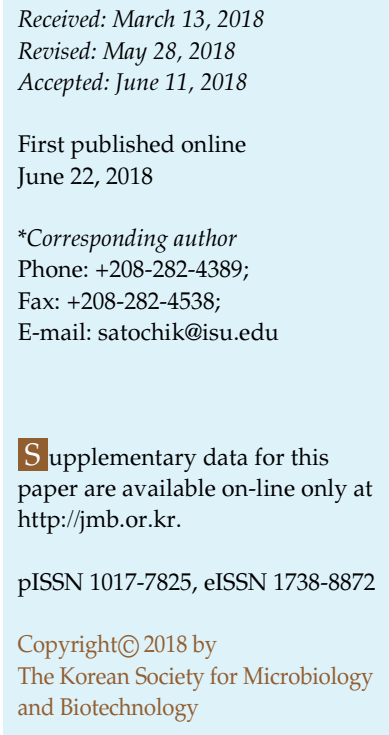

S upplementary data for this paper are available on-line only at http://jmb.or.kr.

pISSN 1017-7825, eISSN 1738-8872

Copyright(C) 2018 by

The Korean Society for Microbiology and Biotechnology

The fungi associated with termites secrete enzymes such as laccase (multi-copper oxidase) that can degrade extracellular wood matrix. Laccase uses molecular oxygen as an electron acceptor to catalyze the degradation of organic compounds. Owing to its ability to transfer electrons from the cathodic electrode to molecular oxygen, laccase has the potential to be a biocatalyst on the surface of the cathodic electrode of a microbial fuel cell (MFC). In this study, a twochamber MFC using the laccase-producing fungus Galactomyces reessii was investigated. The fungus cultured on coconut coir was placed in the cathode chamber, while an anaerobic microbial community was maintained in the anode chamber fed by industrial rubber wastewater and supplemented by sulfate and a $\mathrm{pH}$ buffer. The laccase-based biocathode MFC (lbMFC) produced the maximum open circuit voltage of $250 \mathrm{mV}$, output voltage of $145 \mathrm{mV}$ (with a 1,000 $\Omega$ resistor), power density of $59 \mathrm{~mW} / \mathrm{m}^{2}$, and current density of $278 \mathrm{~mA} / \mathrm{m}^{2}$, and a $70 \%$ increase in half-cell potential. This study demonstrated the capability of laccaseproducing yeast Galactomyces reessii as a biocatalyst on the cathode of the two-chamber lbMFC.

Keywords: Laccase, electricity generation, microbial fuel cell, coconut coir, biocatalyst

\section{Introduction}

Microbial fuel cells (MFCs) directly convert chemical energy to electrical energy using exoelectrogenic bacteria as the biocatalyst. This biotechnology has attracted extensive attention as an innovative way to treat wastewater while recovering energy from wastes [1, 2]. In recent years, many studies have focused on enhancing electricity generation and lowering operation costs toward large-scale or realworld applications. For example, a recent design of an MFC, the so-called up-flow bio-filter circuit, was developed to treat various types of industrial wastewater, such as seafood, biodiesel, and palm oil mill wastewater, without chemical pretreatment and exogenous nutrient supplements [3]. To obtain high electric power outputs, however, many MFCs have used precious metals such as white gold or platinum $(\mathrm{Pt})$ on the surface of the cathodic electrode. The use of such high-price metals has limited the wide applications of the MFCs.

In nature, white-rot fungi produce and secrete extracellular laccase to return nutrients from the plant material to the soil via lignin degradation. This copper-containing oxidoreductase enzyme plays a crucial role in transferring electrons from phenolic compounds and aromatic amines to atmospheric oxygen $\left(\mathrm{O}_{2}\right)$. Accordingly, laccase has the ability to transfer electrons from the cathodic electrode to 
$\mathrm{O}_{2}$, contributing to the degradation of recalcitrant aromatic compounds $[4,5]$. In previous studies with the fungal enzyme immobilized on the surface of the cathode, laccase obtained from fungi like Ganodium lucidum strain BCRC 36123, Trametes versicolor, and Pleurotus ostreatus has successfully enhanced the generation of electricity [6-10]. Nevertheless, the enzymes commercially available from the fungal sources and others are quite expensive, as they are produced via a laborious purification process. Furthermore, enzymes are subject to denaturing under the harsh environmental conditions, resulting in a rapid decrease in their activity [10]. Consequently, the inactive enzymes need to be replaced by fresh enzymes during the MFC operation. Recently, several studies have addressed the problem associated with the immobilized pure enzyme by using whole fungal cells. The newly designed MFC with laccase-producing fungus on the cathodic electrode outperformed the laccase-free MFC (control) in generating electricity [9].

The present study explores the possibility of cultivating the laccase-secreting fungus Galactomycess reessii on the cathode of the two-chamber MFC. G. reessii is generally associated with termites [11] and secretes enzymes such as laccase (multi-copper oxidase) that can degrade extracellular wood matrix (E.C. 1.10.3.2). The mixture of synthetic rubber wastewater containing sulfate and sludge from a rubber industry was applied to the anode chamber as a fuel source to generate electricity.

\section{Materials and Methods}

\section{Preparation of Anodic Consortia}

Rubber wastewater sludge was collected from a sheet rubber wastewater plant in the Tamode District, Phatthalung Province, Thailand. The sludge samples were transferred to the laboratory and stored at $-20^{\circ} \mathrm{C}$ until used. Ten grams (g) of sludge was inoculated into $100 \mathrm{ml}$ of fundamental nutrient broth $(10 \mathrm{~g} / 1$ peptone, $10 \mathrm{~g} / 1$ beef extract, and $5 \mathrm{~g} / 1$ sodium chloride), and then incubated on a shaker table at $150 \mathrm{rpm}$ at $30^{\circ} \mathrm{C}$ for $24 \mathrm{~h}$.

\section{DGGE Analysis of Rubber Wastewater Sludge}

Total genomic DNA (gDNA) was extracted from $10 \mathrm{~g}$ of rubber wastewater sludge using a TIANamp Genomic DNA kit (Tiangen, China). The microbial community of the wastewater sludge was studied by using the modified method of DGGE genetic analysis according to Muyzer et al. [12] and de Lillo et al. [13]. Briefly, the $16 \mathrm{~S}$ ribosomal RNA gene was amplified from gDNA using the universal primer pairs 27f (5'-AGAGTTTGATCMTGGCTCAG-3') and 1525r (5'-AAGGAGGTGWTCCARCC-3'). The $16 \mathrm{~S}$ rRNA

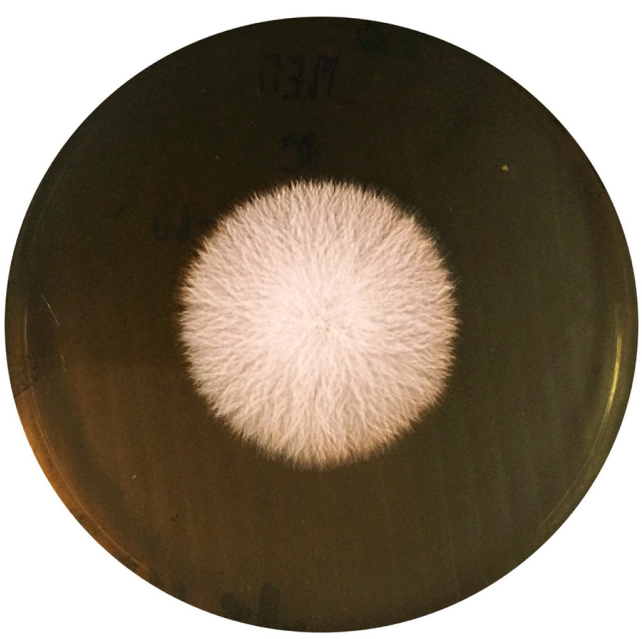

Fig. 1. A Galactomyces reessii colony on potato dextrose agar after incubation at $30^{\circ} \mathrm{C}$ for 7 days.

products were separated on a $1.5 \%$ agarose gel for $30 \mathrm{~min}$ at $100 \mathrm{~V}$. Then, the V3 regions were amplified from the 16S rRNA PCR products using the 357f-GC clamp (5'-CGCCCGCCGCGCGCGGCG GGCGGGGCGGGGGCACGGGGGGCCTACGGGAGGCAGCAG $\left.-3^{\prime}\right)$ and 518r (5'-ATTACCGCGGCTGCTGG-3'). The DGGE profile of the bacterial population from the sludge sample was generated on an $8 \%$ polyacrylamide gel with $40-60 \%$ gradient denaturant solution for $16 \mathrm{~h}$ at $70 \mathrm{~V}$ in $1 \times$ Tri-acetate EDTA buffer at $60^{\circ} \mathrm{C}$.

\section{Preparation of the Cathodic Consortium}

The cathodic consortium was prepared in five stages (Fig. S1). First, the laccase-producing yeast G. reessii was inoculated onto potato dextrose agar (PDA; Sigma-Aldrich, USA) and incubated at $30^{\circ} \mathrm{C}$ for 7 days (Fig. 1). Second, an agar plug $(1 \mathrm{~cm} \times 1 \mathrm{~cm})$ of the activated culture was cut using the sterile technique, and dropped into potato dextrose broth (Sigma-Aldrich, USA). The culture was incubated on a shaker at $150 \mathrm{rpm}$ at $30^{\circ} \mathrm{C}$ for 7 days. Third, $1 \mathrm{~g}$ of sterile coconut coir was filled with $0.7 \mathrm{ml}$ of culture broth, and incubated at $30^{\circ} \mathrm{C}$ for 7 days. The solid-state consortium was saved to be used in future studies (for Stages 4 and 5).

\section{Operation of the Laccase-Based Biocathode MFC (lbMFC)}

The two-chamber MFC (Fig. 2) consisted of an anode chamber $(10 \mathrm{ml})$ and air-cathode chamber $(10 \mathrm{ml})$, which were constructed using acrylic boxes. These two chambers were interfaced through a Nafion HP proton exchange membrane (PEM) sheet $(5.0 \mathrm{~cm}$ diameter). The anode electrode was made from plain carbon cloth. Three types of cathode electrodes were used: (i) Vulcan-carbon cloth coated with $0.03 \mathrm{mg} / \mathrm{cm}^{2} \mathrm{Pt}$ (positive control); (ii) plain carbon cloth with coconut coir (negative control); and (iii) plain carbon cloth $(5.0 \mathrm{~cm}$ electrode diameter) with G. reessii cultured for 7 days on coconut coir. 
As is shown in Fig. 2, the cathode chamber was open to atmosphere. In the cathode chamber, 7-days-old yeast grown on coconut coir was placed. The coconut coir was attached to the carbon cloth (cathodic electrode), which was also exposed to air. The anode chamber was a closed system filled with anolyte inoculated with sludge from a rubber wastewater treatment plant. The carbon cloth served as an anodic electrode. The MFCs were placed inside the environmental chamber that had been cleaned with $70 \%$ ethanol and irradiated by a UV lamp for $30 \mathrm{~min}$, and operated under laminar air flow.

The anolyte comprised $1 \mathrm{ml}$ of sludge obtained from a rubber wastewater treatment plant and $9 \mathrm{ml}$ of synthetic wastewater containing $500 \mathrm{mg} / 1$ sulfate (modified from Mohammadi et al. [14]; Lai et al. [15]). Briefly, the synthetic wastewater comprised $0.7395 \mathrm{~g} / 1 \mathrm{Na}_{2} \mathrm{SO}_{4}$ and $100 \mathrm{mM}$ of a $\mathrm{pH} 7$ phosphate buffer $\left(61.5 \mathrm{ml} / 1\right.$ of $1 \mathrm{M} \mathrm{K}_{2} \mathrm{HPO}_{4}$ and $38.5 \mathrm{ml} / 1$ of $\left.1 \mathrm{M} \mathrm{KH}_{2} \mathrm{PO}_{4}\right)$. This synthetic wastewater was supplied to the MFC every 3 days, and $100 \mu \mathrm{l}$ of ethyl acetate was added as co-substrate to the anode chamber every $24 \mathrm{~h}$. The experiment was carried out with three replicates.

\section{Electrochemical Analysis}

The electrochemical properties (e.g., voltage, current density, power density) were determined by the method modified from the study by Lai et al. [15]. The MFCs were stabilized for 7 days prior to the data acquisition. The open circuit voltage (OCV) was measured for 7 days in each run cycle of the continuous operation. The effects of different resistance loads on the MFC performance was evaluated with the electrodes connected with 390, 500, and $1,000 \Omega$ external resistors. The cathode potential between the coconut coir and the carbon cloth cathode was measured using an $\mathrm{Ag} / \mathrm{AgCl}$ reference electrode $\left(201 \mathrm{mV}\right.$ vs. SHE) at $30^{\circ} \mathrm{C}$. The $\mathrm{Ag} / \mathrm{AgCl}$ reference electrode was inserted into a fuzzy mass of the coconut coir, whereas the other terminal was in contact with the carbon cloth cathode.

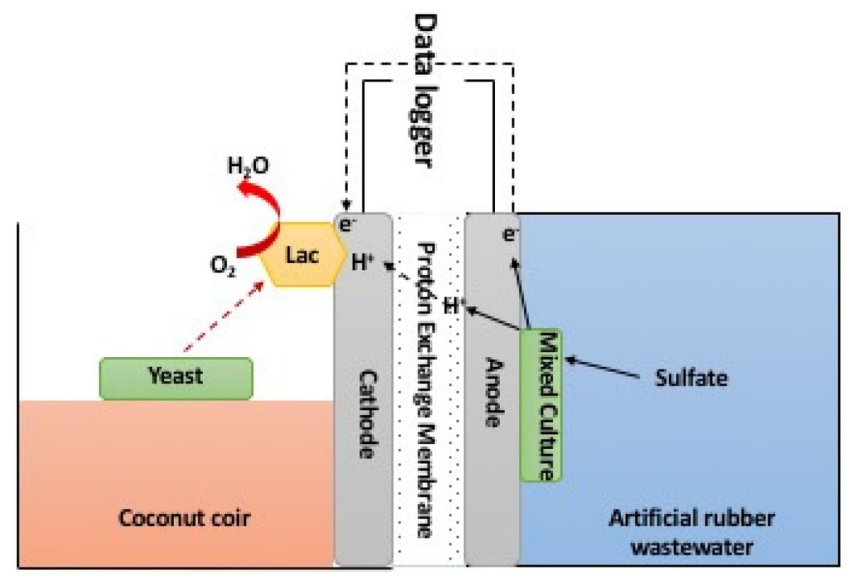

Fig. 2. Diagram of the laccase (Lac)-based two-chamber microbial fuel cell with Galactomyces reessii yeast.

\section{Results and Discussion}

\section{Microbial Community}

As shown in Fig. 3, the microbial populations in the rubber wastewater sludge used in this study were predominantly Moraxellaceae bacterium, Kamptonema formosum, filamentous cyanobacterium, and other uncultured bacteria. On the other hand, the bacterial Moraxellaceae sp. was found in the broad range of sources, such as wastewater treatment plant sludge, lake sediment [16], activated sludge in a continuous up-flow reactor [17], and sea water [18], whereas the cyanobacteria Kamptonema sp. were found spread in wet soil, plant bark, and stream sand [19]. For natural rubber wastewater, Tanikawa et al. [20] showed that the large member of clones related to the sulfate-reducing bacteria families Desulforomonadaceae sp., Desulfobacteraceae sp., and Desulfomicrobiaceae sp. were detected from sludge by microbial community analysis targeting 16S rRNA genes. Watari et al. [21] reported that Bacteroidetes, Firmicutes, Proteobacteria. and Euryarchaeota were predominant microbial groups in rubber wastewater sludge [21].

\section{Open Circuit Voltage}

Table 1 presents the maximum OCV values obtained from this study and other comparative studies. As is seen,

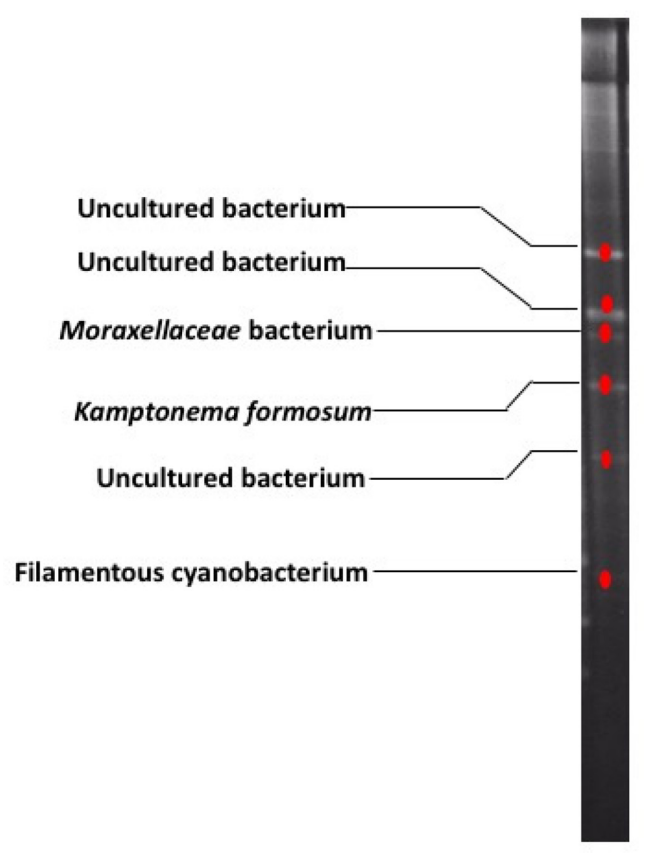

Fig. 3. DGGE analysis of the microbial populations in a rubber wastewater treatment plant. 
Table 1. Open circuit voltages of the fungal-based cathode microbial fuel cells (MFCs).

\begin{tabular}{lllcc}
\hline \multicolumn{1}{c}{ Source } & Catalyst & \multicolumn{1}{c}{ Type of MFC } & Potential at open circuit (mV) & Reference \\
\hline Galactomyces reessii & Laccase & Two-chamber MFC & $249.67 \pm 3.21$ & This study \\
Positive & Platinum & Two-chamber MFC & $272.33 \pm 3.51$ & This study \\
Negative & No & Two-chamber MFC & $202.33 \pm 8.02$ & This study \\
Trametes versicolor & Laccase & H-type MFC & 180 & {$[8]$} \\
Ganodium lucidum strain BCRC 36123 & Laccase & Two-chamber MFC & 699 & {$[14]$} \\
Ganodium lucidum strain BCRC 36123 & Laccase & Single-chamber MFC & 821 & {$[9]$} \\
\hline
\end{tabular}

the $1 \mathrm{bMFC}$ produced the OCV of $249.67 \pm 3.21 \mathrm{mV}$, which was $23.8 \%$ higher than the $202.33 \pm 8.02 \mathrm{mV}$ generated by the negative control. However, the OCV generated by the laccase-based MFC was somewhat lower than the $272.33 \pm 3.51 \mathrm{mV}$ generated by the Pt-cathode (positive control). Wu et al. [8] reported that Trametes versicolor (laccase-secreting white-rot fungus) immobilized on the cathode surface produced the maximum OCV of $180 \mathrm{mV}$. Lai et al. [15] used the laccase-producing white-rot fungus Ganodium lucidum strain BCRC 36123 in the two-chamber MFC for the removal of synthetic dye acid orange 7 (AO7) and generation of electricity. Their biocathode MFC produced the maximum OCV of $699 \mathrm{mV}$ with the decolorization efficiency of $96.7 \%$. The single-chamber MFC with fungal laccase of G. lucidum strain BCRC 36123 produced the maximum OCV of $821 \mathrm{mV}$ and $77 \%$ decolorization [9].

\section{Internal Resistance}

The cell potential is shown in Fig. 4. The electric power outputs are summarized in Table 2. The maximum power densities produced by the lbMFC, positive control, and negative control were 59,59 , and $49 \mathrm{~mW} / \mathrm{m}^{2}$ and the current densities were 278,278 , and $253 \mathrm{~mA} / \mathrm{m}^{2}$, respectively. It should be noted that the maximum voltage, current, and power generated by $\mathrm{lbMFC}$ were the same as those produced by the positive control (Pt-cathode). Also note that the maximum voltage, current, and power generated by the IbMFC were higher than those produced by the negative control (coconut coir-cathode). The two-chamber MFC with the laccase-producing fungus planted on the

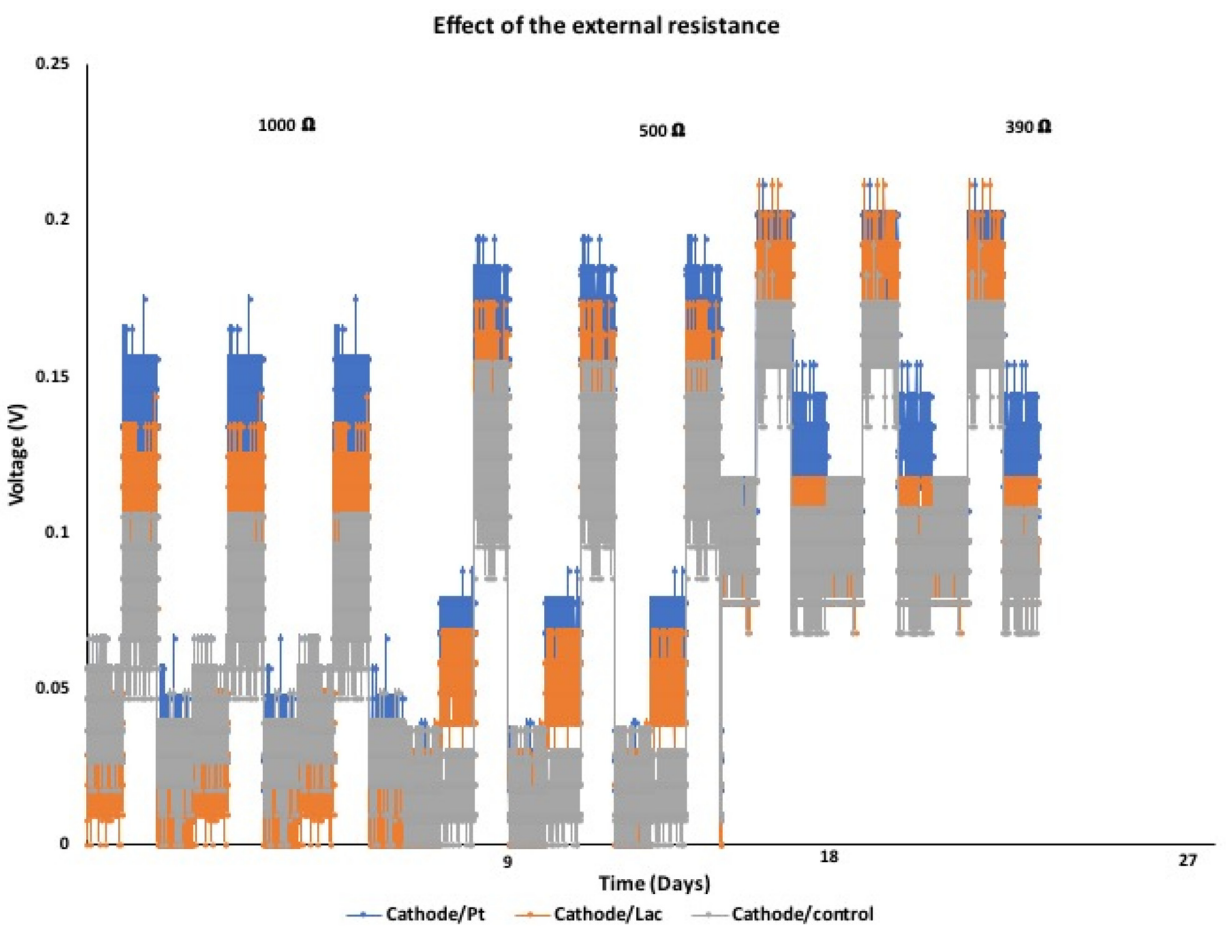

Fig. 4. Effects of the different external resistance loads. 
Table 2. Electrochemical properties of the laccase-based microbial fuel cell.

\begin{tabular}{ccccccccc}
\hline Properties & $\begin{array}{c}\text { Resistance } \\
(\mathrm{Ohm})\end{array}$ & $\begin{array}{c}\text { Voltage } \\
(\mathrm{V})\end{array}$ & $\begin{array}{c}\text { Current } \\
(\mathrm{mA})\end{array}$ & $\begin{array}{c}\text { Current density } \\
\left(\mathrm{mA} / \mathrm{m}^{2}\right)\end{array}$ & $\begin{array}{c}\text { Current density } \\
\left(\mathrm{mA} / \mathrm{m}^{3}\right)\end{array}$ & $\begin{array}{c}\text { Power } \\
(\mathrm{mW})\end{array}$ & $\begin{array}{c}\text { Power density } \\
\left(\mathrm{mW} / \mathrm{m}^{2}\right)\end{array}$ & $\begin{array}{c}\text { Power density } \\
\left(\mathrm{mW} / \mathrm{m}^{3}\right)\end{array}$ \\
\hline Positive & 1,000 & 0.176 & 0.176 & 90 & 1,760 & 0.031 & 16 & 310 \\
& 500 & 0.195 & 0.390 & 199 & 3,900 & 0.076 & 39 & 761 \\
Laccase & 390 & 0.213 & 0.546 & 278 & 5,462 & 0.116 & 59 & 1,163 \\
& 1,000 & 0.145 & 0.145 & 74 & 1,449 & 0.021 & 11 & 210 \\
Negative & 500 & 0.174 & 0.348 & 177 & 3,480 & 0.061 & 31 & 606 \\
& 390 & 0.213 & 0.546 & 278 & 5,459 & 0.116 & 59 & 1,162 \\
& 1,000 & 0.106 & 0.106 & 54 & 1,060 & 0.011 & 6 & 112 \\
& 500 & 0.155 & 0.309 & 158 & 3,092 & 0.048 & 24 & 478 \\
\end{tabular}

${ }^{\text {a }}$ Based on the anode volume.

cathode investigated by Lai et al. [9] yielded the power density of $13.4 \mathrm{~mW} / \mathrm{m}^{2}\left(268 \mathrm{~mW} / \mathrm{m}^{3}\right)$ and the current density of $33 \mathrm{~mA} / \mathrm{m}^{2}\left(660 \mathrm{~mA} / \mathrm{m}^{3}\right)$, whereas the singlechamber MFC with the laccase-producing white-rot fungus grown on the cathode produced the power density of $208 \mathrm{~mW} / \mathrm{m}^{2}\left(225 \mathrm{~mW} / \mathrm{m}^{3}\right)$ and the current density of $585 \mathrm{~mA} / \mathrm{m}^{2}\left(634 \mathrm{~mA} / \mathrm{m}^{3}\right)$ [15]. The power density and current density (based on the PEM area) obtained in the present study are larger than those reported by Lai et al. [9] and smaller than those by Lai et al. [15]. It appears that single-chamber MFCs can produce larger power outputs.

To determine the optimal resistance for this MFC system, the internal resistance of three types of MFCs was calculated using the formula (Nilsson and Riedel [22])

$$
R_{\mathrm{s}}=\left(V_{\mathrm{s}} R_{\mathrm{L}} / V_{\mathrm{o}}\right)-R_{\mathrm{L}}
$$

where $R_{\mathrm{s}}$ and $R_{\mathrm{L}}$ are the internal resistance and load resistance, respectively, and $V_{\mathrm{s}}$ and $V_{\mathrm{o}}$ are the open circuit voltage and output voltage (voltage measured with the load resistance), respectively. At the load resistance $R_{\mathrm{L}}$ of

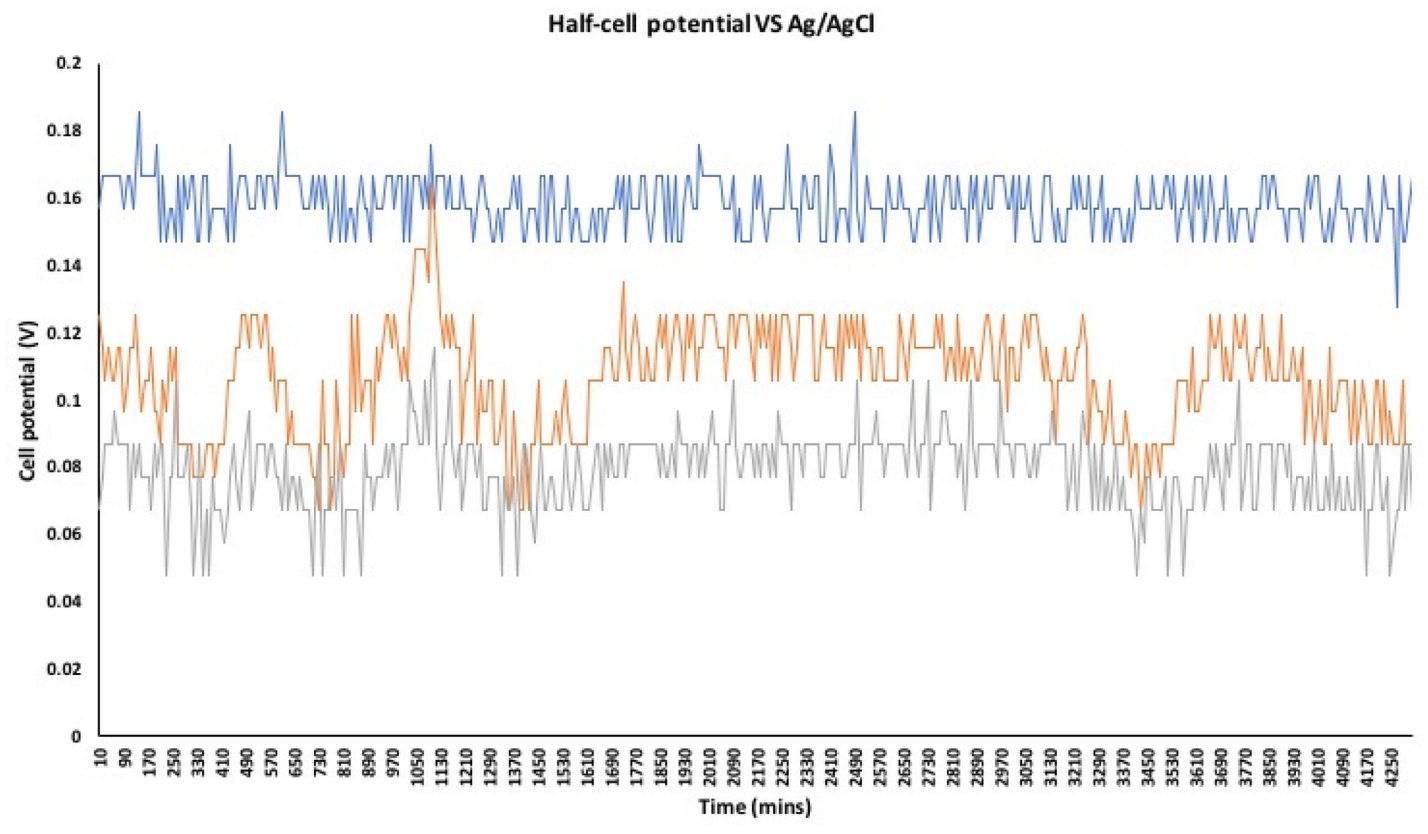

- Cathode/Pt Cathode/Lac Cathode/control

Fig. 5. Cathode potential of the laccase-based microbial fuel cell. 
Table 3. Comparison of the cathode potential of different cathodes with a saturated $\mathrm{Ag} / \mathrm{AgCl}$ reference electrode.

\begin{tabular}{lccc}
\hline \multicolumn{1}{c}{ Cathode types } & Cathode potential $(\mathrm{mV})$ & Increasing from negative $(\%)$ & Comparing with positive $(\%)$ \\
\hline $\mathrm{Pt}$ (positive control) & $185.7 \pm 0.8$ & 71.3 & 100.0 \\
Galactomyces reessii on coconut coir & $164.3 \pm 2.6$ & 48.6 & 68.2 \\
Sterile coconut coir (negative control) & $115.7 \pm 3.8$ & 0.0 & 0.0 \\
\hline
\end{tabular}

$1,000 \Omega$, the internal resistance $R_{\mathrm{s}}$ values calculated for the lbMFC, positive control, and negative control are 725, 545, and $906 \Omega$, respectively. In theory [22], as the maximum power is produced when $R_{\mathrm{L}}=R_{\mathrm{s}}$, the result indicates that the power output from the negative control was close to the maximum, and that the power output from the lbMFC and positive control MFC can be enhanced by using smaller resistance loads. The internal resistance of the two-chamber MFC with the white-rot fungus G. lucidum used by Lai et al. [9] was $1,574 \Omega$.

\section{Cathode Potential}

Fig. 5 shows the cathode potential produced by the three different cathode settings; namely, the fungal cathode, sterile coconut-coir cathode (negative control), and Pt-cathode (positive control). The results are summarized in Table 3. A comparison of the cathode potential shows that the lbMFC produced the maximum potential of $164.3 \pm 2.6 \mathrm{mV}$, which was higher than the $115.7 \pm 3.8 \mathrm{mV}$ produced by the negative control and lower than the $185.7 \pm 0.8 \mathrm{mV}$ yielded by the positive control. The cathode with $G$. reessii produced a $70 \%$ higher potential than the negative control. Lai et al. [9] planted the medical Lingzhi and Reishi mushroom (Ganoderma lucidum) on the cathode of a single-chamber MFC and used wood chips as substrate to generate electricity and remove the azo dye AO7. In their system, the fungal-fixed cathode produced the maximum potential of $20 \mathrm{mV}$ (vs. $\mathrm{Ag} / \mathrm{AgCl}$ ). Morant et al. [23] grew the filamentous fungi Rhizopus sp., Aspergillus sp., and Penicillium sp. (sources of oxidase enzymes such as bilirubin oxidase and laccase) in a saline medium containing copper sulfate $\left(\mathrm{CuSO}_{4}\right)$ as an enzyme inducer to enhance electricity generation. In their system (submerged cultures), Rhizopus sp., Aspergillus sp., and Penicillium sp. produced 327.73, 288.80, and $197.77 \mathrm{~mW} / \mathrm{m}^{3}$ respectively. In the present study without enzyme inducer $\left(\mathrm{CuSO}_{4}\right)$ and medium, the two-chamber MFC with the G. reessii cathode produced the maximum potential of $145 \mathrm{mV}$ (with 1,000 $\Omega$ resistance), power density of $59 \mathrm{~mW} / \mathrm{m}^{2}$, and current density of $278 \mathrm{~mA} / \mathrm{m}^{2}$.

The MFC with the laccase-based biocathode is expected to reduce the MFC construction costs, as it does not use precious metals, and the operation costs because it does not use pure enzyme and exogenous substrate (culture media and mediator). The lbMFC uses the cathode having whole fungal cells, and it does not require a continuous supply of fresh enzyme and exogenous substrate. Because of these features, the MFC developed in this study has potential for scale-up in field applications. Nonetheless, further studies are needed to enhance the power production, reliability, robustness, scale-up potential, and cost effectiveness.

In conclusion, this study indicated that the means of solid-state fermentation to grow the laccase-producing yeast $G$. reessii improved the generation of electricity, and that coconut coir could serve as an ultimate substrate to support the growth of the yeast and production of laccase without the use of chemical (e.g., $\mathrm{CuSO}_{4}$ ) and culture media (e.g., PDA). G. reessii was cultured on coconut coir and planted in the cathode chamber, while an anaerobic microbial community was maintained in the anode chamber that was fed industrial rubber wastewater with supplements. The results showed that the MFC with G. reessii produced the maximum OCV of $250 \mathrm{mV}$, and that with a $390 \Omega$ resistor, it produced the output voltage of $213 \mathrm{mV}$, power density of $59 \mathrm{~mW} / \mathrm{m}^{2}$, and current density of $278 \mathrm{~mA} / \mathrm{m}^{2}$, and a $70 \%$ increase in cathode potential as compared with the negative control (absence of G. reessii). This study demonstrated that the laccase-producing yeast $G$. reessii can serve as a biocatalyst in the cathode of the two-chamber MFC.

\section{Acknowledgments}

The authors would like to thank the Department of Energy under the Thailand government and the Science Achievement Scholarship of Thailand for financial support.

\section{Conflict of Interest}

The authors have no financial conflicts of interest to declare.

\section{References}

1. Logan BE, Rabaey K. 2012. Conversion of wastes into 
bioelectricity and chemicals by using microbial electrochemical technologies. Science 337: 686-690.

2. Zhang F, Chen M, Zhang Y, Zeng RJ. 2012. Microbial desalination cells with ion exchange resin packed to enhance desalination at low salt concentration. J. Memb. Sci. 417: $28-33$.

3. Sukkasem C, Laehlah S. 2013. Development of a UBFC biocatalyst fuel cell to generate power and treat industrial wastewaters. Bioresour. Technol. 146: 749-753.

4. Pozdnyakova NN, Rodakiewicz-Nowak J, Turkovskaya OV, Haber J. 2006. Oxidative degradation of polyaromatic hydrocarbons catalyzed by blue laccase from Pleurotus ostreatus D1 in the presence of synthetic mediators. Enzyme Microb. Technol. 39: 1242-1249.

5. Lee H, Jang Y, Choi YS, Kim MJ, Lee J, Lee H, et al. 2014. Biotechnological procedures to select white rot fungi for the degradation of PAHs. J. Microbiol. Methods 97: 56-62.

6. Barton SC, Pickard M, Vazquez-Duhalt R, Heller A. 2002. Electroreduction of O-2 to water at $0.6 \mathrm{~V}$ (SHE) at $\mathrm{pH} 7$ on the 'wired' Pleurotus ostreatus laccase cathode. Biosens. Bioelectron. 17: 1071-1074.

7. Fishilevich S, Amir L, Fridman Y, Aharoni A, Alfonta L. 2009. Surface display of redox enzymes in microbial fuel cells. J. Am. Chem. Soc. 131: 12052-12053.

8. Wu C, Liu XW, Li WW, Sheng GP, Zang GL, Cheng YY, et al. 2012. A white-rot fungus is used as a biocathode to improve electricity production of a microbial fuel cell. Appl. Energy 98: 594-596.

9. Lai CY, Wu CH, Meng CT, Lin CW. 2017. Decolorization of azo dye and generation of electricity by microbial fuel cell with laccase-producing white-rot fungus on cathode. Appl. Energy 188: 392-398.

10. Mani P, Keshavarz T, Chandra TS, Kyazze G. 2017. Decolourisation of acid orange 7 in a microbial fuel cell with a laccase-based biocathode: influence of mitigating $\mathrm{pH}$ changes in the cathode chamber. Enzyme Microb. Technol. 96: 170-176.

11. Chaijak P, Lertworapreecha M, Sukkasem C. 2018. Phenol removal from palm oil mill effluent using Galactomyces Reessii termite-associated yeast. Pol. J. Environ Stud. 27: 39-44.

12. Muyzer G, Dewaal EC, Uitterlinden AG. 1993. Profiling of complex microbial populations by denaturing gradient gel electrophoresis analysis of polymerase chain reactionamplified genes coding for $16 \mathrm{~S}$ ribosomal RNA. Appl. Environ. Microbiol. 59: 695-700.
13. de Lillo A, Ashley FP, Palmer RM, Munson MA, Kyriacou L, Weightman AJ, et al. 2006. Novel subgingival bacterial phylotypes detected using multiple universal polymerase chain reaction primer sets. Oral Microbiol. Immunol. 21: 61-68.

14. Mohammadi M, Man HC, Hassan MA, Yee PL. 2010. Treatment of wastewater from rubber industry in Malaysia. Afr. J. Biotechnol. 9: 6233-6243.

15. Lai CY, Liu SH, Wu GP, Lin CW. 2017. Enhanced biodecolorization of acid orange 7 and electricity generation in microbial fuel cells with superabsorbent-containing membrane and laccase-based bio-cathode. J. Clean. Prod. 166: 381-386.

16. Chu BTT, Petrovich ML, Chaudhary A, Wright D, Murphy B, Wells G, et al. 2018. Metagenomics reveals the impact of wastewater treatment plants on the dispersal of microorganisms and genes in aquatic sediments. Appl. Environ. Microbiol. 84: e02168-17.

17. Sun HH, Yu P, Li QL, Ren HQ, Liu B, Ye L, Zhang XX. 2017. Transformation of anaerobic granules into aerobic granules and the succession of bacterial community. Appl. Microbiol. Biotechnol. 101: 7703-7713.

18. Oh KH, Lee SY, Lee MH, Oh TK, Yoon JH. 2011. Paraperlucidibaca baekdonensis gen. nov., sp nov., isolated from seawater. Int. J. Syst. Evol. Microbiol. 61: 1382-1385.

19. Martins MD, Rigonato J, Taboga SR, Branco LHZ. 2016. Proposal of Ancylothrix gen. nov., a new genus of Phormidiaceae (Cyanobacteria, Oscillatoriales) based on a polyphasic approach. Int. J. Syst. Evol. Microbiol. 66: 2396-2405.

20. Tanikawa D, Syutsubo K, Hatamoto M, Fukuda M, Takahashi M, Choeisai PK, et al. 2016. Treatment of natural rubber processing wastewater using a combination system of a two-stage up-flow anaerobic sludge blanket and downflow hanging sponge system. Water Sci. Technol. 73: 1777-1784.

21. Watari T, Thanh NT, Tsuruoka N, Tanikawa D, Kuroda K, Huong $\mathrm{N}$, et al. 2016. Development of a BR-UASB-DHS system for natural rubber processing wastewater treatment. Environ. Technol. 37: 459-465.

22. Nilsson JM, Riedel SA. 2011. Techniques of circuit analysis, pp. 88-143. In Horton MJ, Gilfillan A, Opaluch W, Galligan T, Disanno S, Kernan R, Fischer A, Beck K, Carney K (eds.), Electric Circuits, $9^{\text {th }}$ Ed. Pearson Education, New Jersey.

23. Morant KV, da Silva PH, de Campos-Takaki GM, Hernandez CEL. 2014. Isolation and bioelectrochemical characterization of novel fungal sources with oxidasic activity applied in situ for the cathodic oxygen reduction in microbial fuel cells. Enzyme Microb. Technol. 66: 20-27. 